\title{
Human Red Cells Scavenge Extracellular Hydrogen Peroxide and Inhibit Formation of Hypochlorous Acid and Hydroxyl Radical
}

\author{
Christine C. Winterbourn and Arnold Stem* \\ Department of Pathology, School of Medicine, Christchurch Hospital, Christchurch, New Zealand; *Department of Pharmacology, \\ New York University Medical Center, New York 10016
}

\begin{abstract}
The ability of intact human red cells to scavenge extracellularly generated $\mathrm{H}_{2} \mathrm{O}_{2}$ and $\mathrm{O}_{2}^{-}$, and to prevent formation of hydroxyl radicals and hypochlorous acid has been examined. Red cells inhibited oxidation of ferrocytochrome $c$ by $\mathrm{H}_{2} \mathrm{O}_{2}$. Cells treated with aminotriazole no longer inhibited, indicating that protection was almost entirely due to intracellular catalase. Contribution by the GSH system was slight, and apparent only with low $\mathrm{H}_{2} \mathrm{O}_{2}$ concentrations when catalase was inhibited by aminotriazole. The cells were about a quarter as efficient at inhibiting cytochrome $c$ oxidation as an equivalent concentration of purified catalase. No inhibition of $\mathrm{O}_{2}^{-}$-dependent reduction of ferricytochrome $c$ or nitroblue tetrazolium was observed, although extracted red cell superoxide dismutase inhibited nitroblue tetrazolium reduction at one fortieth the concentration of that in the cells. Red cells efficiently inhibited deoxyribose oxidation by hydroxyl radicals generated from $\mathrm{H}_{2} \mathrm{O}_{2}, \mathrm{O}_{2}^{-}$and $\mathrm{Fe}(\mathrm{EDTA})$, and myeloperoxidase-dependent oxidation of methionine to methionine sulfoxide by stimulated neutrophils. Most of the red cell inhibition of hydroxyl radical production, and all the inhibition of methionine oxidation, was prevented by blocking intracellular catalase with aminotriazole. Thus red cells are able to efficiently scavenge $\mathrm{H}_{2} \mathrm{O}_{2}$, but not $\mathrm{O}_{2}^{-}$, produced in their environment, and to inhibit formation of hydroxyl radicals and hypochlorous acid. They may therefore have an important role in extracellular antioxidant defense.
\end{abstract}

\section{Introduction}

Red cells are excellently equipped to handle intracellular oxidative stress (1). Through the combined activities of the hexose monophosphate shunt and glutathione peroxidase, superoxide dismutase, and catalase, they are able to protect themselves against oxygen reduced products $\left(\mathrm{O}_{2}^{-}, \mathrm{H}_{2} \mathrm{O}_{2}\right.$, and derived species). Hemoglobin may also remove $\mathrm{O}_{2}^{-}$or $\mathrm{H}_{2} \mathrm{O}_{2}$, since it can function catalytically as an oxidase or a peroxidase $(2,3)$.

Reduced oxygen products generated extracellularly, e.g., in the vasculature, are generally considered to have a free range, because plasma is poorly endowed with scavengers such as superoxide dismutase and catalase $(4,5)$. However, red cell membranes are permeable to $\mathrm{O}_{2}^{-}$and $\mathrm{H}_{2} \mathrm{O}_{2}(6)$, and recent evidence suggests that red cells can protect against oxidant-

Address reprint requests to Dr. Stern.

Received for publication 28 August 1986 and in revised form 25 February 1987.

J. Clin. Invest.

(c) The American Society for Clinical Investigation, Inc. $0021-9738 / 87 / 11 / 1486 / 06 \$ 2.00$

Volume 80, November 1987, 1486-1491 mediated cytotoxicity. Protection against the early death of rats exposed to lethal hyperoxia (7), or against the effects of an $\mathrm{O}_{2}^{-} / \mathrm{H}_{2} \mathrm{O}_{2}$ generating system causing lung edema (8) or lysis of L1210 murine leukemic cells (9), has been observed. $\mathrm{H}_{2} \mathrm{O}_{2}$ has been implicated as the damaging species in these studies, and protection by red cells attributed mainly to either catalase (8, 9) or to GSH metabolism (7). Red cells have also been shown to scavenge $\mathrm{H}_{2} \mathrm{O}_{2}$ generated by stimulated neutrophils (10).

These observations suggest that red cells could be important regulators of oxidant reactions in their surroundings. However, how well they can play this role will depend on their scavenging efficiency relative to other reactions of the oxidants. To assess the scavenging potential of red cells, more quantitative information is required on their ability to inhibit reactions of each oxidant with a specific detector. Reduced oxygen species most likely to be generated in the vicinity of red cells are $\mathrm{O}_{2}^{-}, \mathrm{H}_{2} \mathrm{O}_{2}$, and the more reactive hydroxyl radical $\left(\mathrm{OH}^{\circ}\right)$ and myeloperoxidase-derived oxidants formed from $\mathrm{H}_{2} \mathrm{O}_{2}$ and chloride by stimulated neutrophils. The primary oxidant in the latter case is thought to be hypochlorous acid (HOCl). ${ }^{1}$ Using reduction of ferricytochrome $c$ or nitroblue tetrazolium (NBT) $)^{2}$ for detection of $\mathrm{O}_{2}^{-}$, oxidation of ferrocytochrome $c$ for $\mathrm{H}_{2} \mathrm{O}_{2}$, deoxyribose oxidation for $\mathrm{OH}^{\circ}$, and methionine oxidation to the sulfoxide for $\mathrm{HOCl}$, we have investigated the ability of red cells to scavenge or prevent the formation of these species. We have also determined the mechanism of protection, and compared the efficiency of the cells with that of free catalase or superoxide dismutase.

\section{Methods}

Cells. Human blood was collected daily from healthy donors into heparinized tubes. Red cells were isolated by centrifugation at $1,000 \mathrm{~g}$ for $5 \mathrm{~min}$, removal of plasma and white cells, washing three times with phosphate-buffered saline, pH 7.4 (PBS), and resuspending in PBS at the required hemoglobin concentrations (11). A $1 \%$ suspension corresponded to $3 \mathrm{~g}$ hemoglobin or $10^{11}$ cells/liter.

Red cell catalase was inhibited by incubating a $25 \%$ cell suspension with $0.05 \mathrm{M}$ 3-amino-1,2,4-triazole and $4.5 \mathrm{mM} \mathrm{H}_{2} \mathrm{O}_{2}$ for $1 \mathrm{~h}$ at $37^{\circ} \mathrm{C}$, then washing three times with PBS. Catalase activity was measured in red cell lysates by observing the decrease in $A_{240}$ of $10 \mathrm{mM} \mathrm{H}_{2} \mathrm{O}_{2}$ (11). A unit is defined as causing a decrease in $A_{240}$ of 0.34 per min. Red cell GSH was blocked by treating a $25 \%$ cell suspension with $2.5 \mathrm{mM}$

1. We have referred to the myeloperoxidase-derived oxidant as $\mathrm{HOCl}$, throughout the text. Under the conditions of our study, methionine oxidation should have been almost entirely due to $\mathrm{HOCl}$, either forming the sulfoxide directly, or via methionine chloramine as an intermediate. To the extent that other amines present were able to trap $\mathrm{HOCl}$, the resultant chloramines would have contributed to oxidation, and the term $\mathrm{HOCl}$ also encompasses these oxidants.

2. Abbreviations used in this paper: DDC, diethyldithiocarbamate; NBT, nitroblue tetrazolium; NEM, N-ethylmaleimide. 
$N$-ethylmaleimide (NEM) for $30 \mathrm{~min}$ at $37^{\circ} \mathrm{C}$, then washing three times with PBS. This was sufficient to bind all the GSH and to diminish shunt activity by $50 \%$ or less (12). GSH was measured by the method of Beutler (11).

Red cell superoxide dismutase was inhibited by incubating a $2 \%$ cell suspension for $2 \mathrm{~h}$ at $37^{\circ} \mathrm{C}$ with $0.1 \mathrm{M}$ diethyldithiocarbamate (DDC), then washing three times with PBS. Chloroform-ethanol extracts of red cell superoxide dismutase were prepared and assayed as described by Winterbourn (13).

Carbomonoxy-red cells were prepared by bubbling a $2 \%$ cell suspension with $\mathrm{CO}$ for $\sim 20 \mathrm{~s}$.

Hemoglobin-free ghosts were prepared (14) from a red cell suspension with known hemoglobin concentration. The final ghost preparation was treated with aminotriazole and $\mathrm{H}_{2} \mathrm{O}_{2}$ (as above) to inhibit residual catalase, washed, and resuspended in PBS to an equivalent hemoglobin concentration.

Neutrophils were prepared from the blood of healthy donors by Ficoll-Hypaque centrifugation, dextran sedimentation, and lysis of contaminating red cells (15).

Superoxide. $\mathrm{O}_{2}^{-}$was generated from hypoxanthine $(150 \mu \mathrm{M})$ and xanthine oxidase $(0.01 \mathrm{U} / \mathrm{ml})$ in the presence of catalase $(600 \mathrm{U} / \mathrm{ml})$, and was detected by reaction with ferricytochrome $c(7.5$ or $15 \mu \mathrm{M})$ or with NBT (12.5-50 $\mu \mathrm{M})$. Reactions, in $1 \mathrm{ml}$ total volume of PBS, were carried out at $37^{\circ} \mathrm{C}$ in the presence of up to $0.4 \%$ red cells. Reduction of cytochrome $c$ was monitored spectrophotometrically by scanning between 650 and $500 \mathrm{~nm}$, a standard interval after adding the enzyme. When red cells were present, the suspension was first centrifuged at $10,000 \mathrm{~g}$ for $1 \mathrm{~min}$, and the spectrum of the supernatant immediately recorded. Reduction of NBT was continuously monitored at $560 \mathrm{~nm}$, in the presence of red cells.

Hydrogen peroxide. $\mathrm{H}_{2} \mathrm{O}_{2}$ was detected by its oxidation of ferrocytochrome $c$, which was prepared by adding a few grains of sodium dithionite to ferricytochrome $c$, and removing the excess dithionite on a column of Sephadex G25 equilibrated with PBS. Reactions were carried out at $37^{\circ} \mathrm{C}$ in PBS, with an initial ferrocytochrome $c$ concentration of $15 \mu \mathrm{M}$, and either $0.9 \mathrm{mM} \mathrm{H}_{2} \mathrm{O}_{2}$ or $5 \mathrm{mM}$ glucose and 160 $\mathrm{U} / \mathrm{ml}$ glucose oxidase (type II, Sigma Chemical Co., St. Louis, MO). This produced $\sim 15 \mu \mathrm{M} \mathrm{H}_{2} \mathrm{O}_{2} / \mathrm{min}$. Spectra between 650 and $500 \mathrm{~nm}$ were recorded at zero time and after a standard interval, catalase $(400$ $\mathrm{U} / \mathrm{ml}$ ) being added to stop the reaction. Red cells were removed by centrifugation, as above.

Hydroxyl radicals. $\mathrm{OH}^{*}$ was generated from hypoxanthine $(150$ $\mu \mathrm{M})$ and xanthine oxidase $(0.007 \mathrm{U} / \mathrm{ml})$ in the presence of $2 \mu \mathrm{M} \mathrm{FeSO}_{4}$ and $50 \mu \mathrm{M}$ EDTA, and was detected by reaction with $10 \mathrm{mM}$ deoxyribose (16). Reactions, in 1-ml total vol of PBS, were carried out for 40 min at $37^{\circ} \mathrm{C}$, in the presence of up to $0.4 \%$ red cells. Trichloroacetic acid $(1 \mathrm{ml}$ of $2.8 \mathrm{~g} / 100 \mathrm{ml})$ was then added, the solutions were centrifuged for $5 \mathrm{~min}$ at $1,000 \mathrm{~g}$, and the supernatants were added to $0.5 \mathrm{ml}$ of thiobarbituric acid reagent (17), heated at $100^{\circ} \mathrm{C}$ for $10 \mathrm{~min}$, and their $A_{532}$ values measured. To examine the effect of red cells on deoxyribose oxidation by radiolytic $\mathrm{OH}^{\circ}$, solutions containing $10 \mathrm{mM}$ deoxyribose and $400 \mathrm{U} / \mathrm{ml}$ catalase, with and without red cells, were bubbled with $\mathrm{N}_{2} \mathrm{O}$ (to enhance the radiolytic $\mathrm{OH}^{\circ}$ yield), and irradiated anaerobically with a Co source to a dose of $10 \mathrm{krad}$. Red cells were removed by centrifugation, and 1-ml portions were analyzed for TBA-reactive products.

Hypochlorous acid. $\mathrm{HOCl}$ was generated by stimulating neutrophils $\left(2 \times 10^{7}\right.$ in $1 \mathrm{ml}$ PBS containing $1 \mathrm{mM} \mathrm{Ca}^{2+}, 0.5 \mathrm{mM} \mathrm{Mg}^{2+}$ and 1 $\mathrm{mg} / \mathrm{ml}$ glucose $)$ with cytochalasin $\mathrm{B}(0.5 \mu \mathrm{l}$ of $5 \mathrm{mg} / \mathrm{ml}$ in dimethylsulfoxide) and phorbol myristate acetate $(0.5 \mu \mathrm{l}$ of $2 \mathrm{mg} / \mathrm{ml}$ in dimethylsulfoxide). The stimulated cells $\left(3 \times 10^{6} / \mathrm{ml}\right)$ were immediately added to PBS containing $1 \mathrm{mM}$ methionine and various concentrations of either red cells or catalase. After $45 \mathrm{~min}$ at $37^{\circ} \mathrm{C}$, the cells were removed by centrifugation and the conversion of methionine to methionine sulfoxide (18) was determined by amino acid analysis of $50 \mu \mathrm{l}$ supernatant. Reactions with $\mathrm{HOCl}$ were performed by adding $\mathrm{HOCl}$ ( $50 \mu \mathrm{l}$ of $5 \mathrm{mM}$ ) with continuous mixing to $1 \mathrm{ml}$ of $1 \mathrm{mM}$ methionine with and without red cells, and measuring conversion to the sulfoxide.
Biochemicals were all obtained from the Sigma Chemical Co., St. Louis, Mo. Myeloperoxidase was purified as in reference (19).

\section{Results}

Hydrogen peroxide. Addition of $\mathrm{H}_{2} \mathrm{O}_{2}$, or the generation of $\mathrm{H}_{2} \mathrm{O}_{2}$ by glucose oxidase and glucose, caused oxidation of ferrocytochrome $c$, and corresponding loss of its $550 \mathrm{~nm}$ peak. As shown in Fig. 1, the rate of oxidation was linearly dependent on $\mathrm{H}_{2} \mathrm{O}_{2}$ concentration. The absorbance difference between the $550-\mathrm{nm}$ peak and the $535 \mathrm{~nm}$ trough gives a quantitative measure of the extent of oxidation. With $15 \mu \mathrm{M}$ cytochrome $c$ and $0.9 \mathrm{mM} \mathrm{H}_{2} \mathrm{O}_{2}, 0.2 \%\left(2 \times 10^{10} /\right.$ liter $)$ or greater red cell suspensions consistently gave almost complete inhibition of oxidation (Fig. 2). With the same cytochrome $c$ concentrations and $\mathrm{H}_{2} \mathrm{O}_{2}(15 \mu \mathrm{M} / \mathrm{min})$ generated with glucose oxidase, $0.2-0.4 \%$ red cells were fully inhibitory (not shown). These findings are in general agreement with those of Toth et al. (8).

The inhibitory capacity of the red cells was compared with that of an equivalent concentration of purified catalase. Complete inhibition of cytochrome $c$ oxidation by $\mathrm{H}_{2} \mathrm{O}_{2}$ was observed with $13 \mathrm{U} / \mathrm{ml}$ or greater of purified catalase. This compares with $53 \mathrm{U} / \mathrm{ml}$ measured in $0.2 \%$ red cell suspensions. Hence the red cells were approximately one quarter as efficient at removing $\mathrm{H}_{2} \mathrm{O}_{2}$ as an equivalent concentration of free catalase.

Red cells preincubated with $\mathrm{H}_{2} \mathrm{O}_{2}$ and the catalase inhibitor, aminotriazole, no longer inhibited ferrocytochrome $c$ oxidation by either $\mathrm{H}_{2} \mathrm{O}_{2}$ (Fig. 3) or glucose and glucose oxidase. This was true whether or not the cells had been pre-incubated with glucose for $1 \mathrm{~h}$ before exposure to $\mathrm{H}_{2} \mathrm{O}_{2}$. Glucose also did not enhance the protection by cells that had not been treated with aminotriazole. Depletion of red cell GSH with NEM did not affect the ability of the cells to inhibit. Neither did treatment with carbonmonoxide, which binds strongly to ferrohemoglobin and markedly decreases its reactivity with other ligands or oxidants (20). The aminotriazole-treated cells turned brown during the incubation, indicating that $\mathrm{H}_{2} \mathrm{O}_{2}$ had reacted with intracellular hemoglobin. However, the amount of $\mathrm{H}_{2} \mathrm{O}_{2}$ consumed within the cells was evidently not enough to appreciably decrease the external concentration and slow its reaction with ferrocytochrome $c$.

Since the above experiments were carried out using relatively high $\mathrm{H}_{2} \mathrm{O}_{2}$ concentrations, no effect of $\mathrm{GSH}$ metabolism may have been evident because the hexose monophosphate shunt was unable to decrease these concentrations signifi-

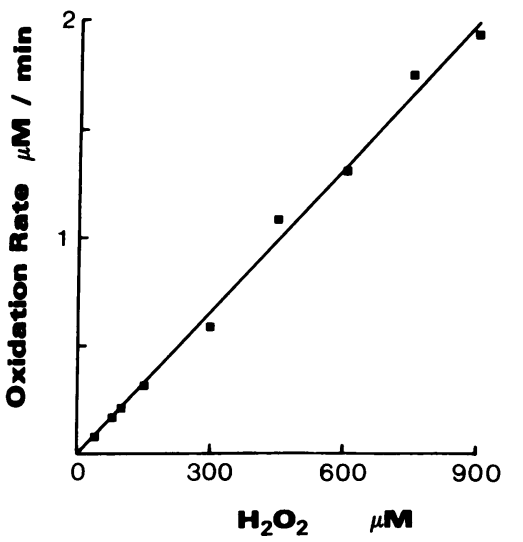

Figure 1. Dependence of the rate of ferrocytochrome $c$ oxidation on $\mathrm{H}_{2} \mathrm{O}_{2}$ concentration. Rates were measured continuously as $\Delta A_{550}$, with an initial ferrocytochrome $c$ concentration of $15 \mu \mathrm{M}$. 


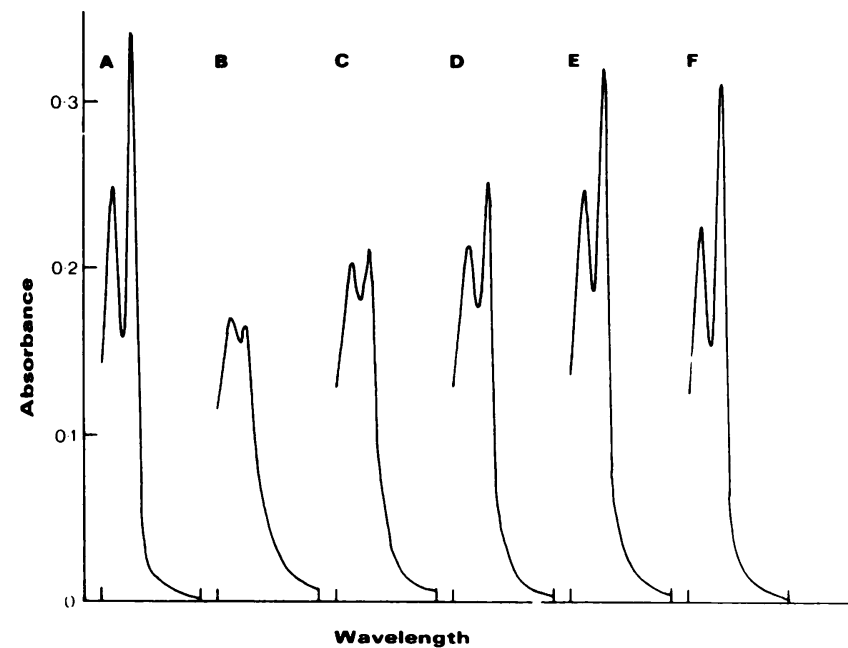

Figure 2. Effect of red cells on oxidation of ferrocytochrome $c$ by $\mathrm{H}_{2} \mathrm{O}_{2}$. Reactions were carried out for $6 \mathrm{~min}$, as described in Methods. Spectra between 500 and $650 \mathrm{~nm}$ were recorded after reaction with $\mathrm{H}_{2} \mathrm{O}_{2}$. (A) ferrocytochrome $c$, no $\mathrm{H}_{2} \mathrm{O}_{2},(B)$ no red cells; $(C) 0.02 \%$ red cells; $(D) 0.05 \%$ red cells; $(E) 0.1 \%$ red cells; $(F) 0.2 \%$ red cells.

cantly. A further experiment was performed, therefore, with $50 \mu \mathrm{M} \mathrm{H}_{2} \mathrm{O}_{2}$ and a 40-min reaction period. Under these conditions $0.02 \%$ or greater red cell suspensions gave almost complete inhibition of ferrocytochrome $c$ oxidation $(81 \pm 1 \%$ inhibition with $0.02 \%$ cells, determined from the change in $A_{550}$ ). Blocking catalase activity with aminotriazole decreased inhibi-

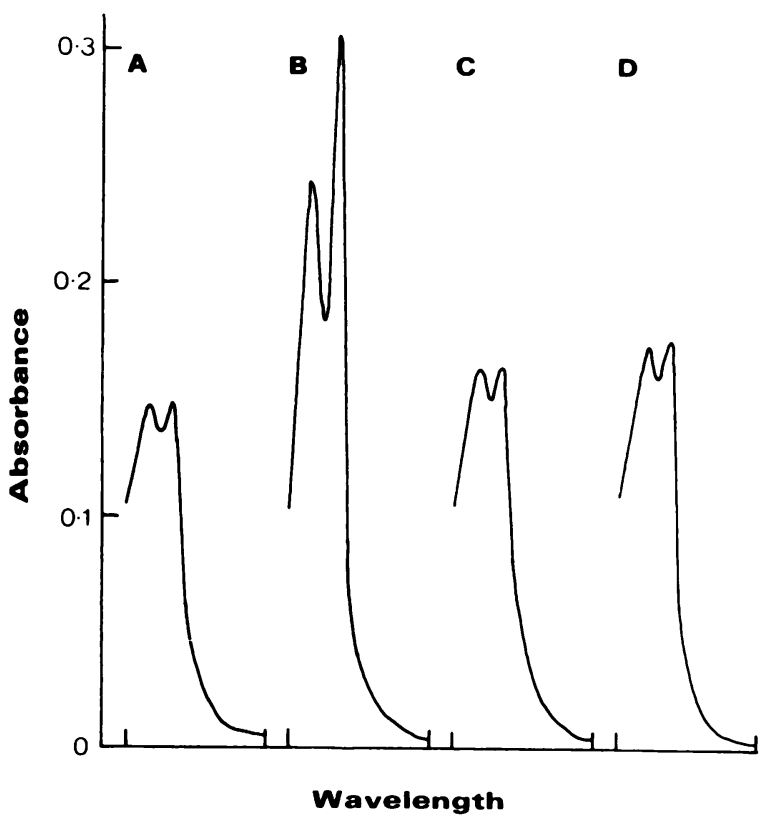

Figure 3. Effect of treating red cells with aminotriazole on their ability to inhibit oxidation of ferrocytochrome $c$ by $\mathrm{H}_{2} \mathrm{O}_{2}$. Conditions were as in Fig. 2, and spectra between 500 and $650 \mathrm{~nm}$ were recorded after reaction with $\mathrm{H}_{2} \mathrm{O}_{2}$. (A) no red cells; $(B) 0.1 \%$ untreated red cells; $(C) 0.1 \%$ aminotriazole-treated red cells; $(D) 0.1 \%$ aminotriazole-treated red cells preincubated with $5 \mathrm{mM}$ glucose; (unreacted ferrocytochrome $c$ is as in Fig. $1 A$ ). tion by the cells to $30 \%$, and a small effect of NEM treatment (77 $\pm 1 \%$ inhibition) was also apparent. However, the effect of blocking GSH was more pronounced when catalase was also inactivated, and a combination of aminotriazole and NEM decreased inhibition to $9 \%$. Glucose addition, in the presence or absence of aminotriazole, had no notable effect.

These results indicate that catalase is the major red cell scavenger of external $\mathrm{H}_{2} \mathrm{O}_{2}$, whether added as a bolus or continuously generated, and that hemoglobin or GSH and glucose metabolism contribute only minimally. Only in the absence of catalase activity, with low $\mathrm{H}_{2} \mathrm{O}_{2}$ concentrations, are effects of GSH-dependent $\mathrm{H}_{2} \mathrm{O}_{2}$ removal apparent.

Superoxide. When red cells (up to $0.4 \%$ ) were added to a solution of xanthine oxidase and hypoxanthine in the presence of $15 \mu \mathrm{M}$ ferricytochrome $c$ and catalase, no significant change in rate of cytochrome $c$ reduction was observed when compared with the same system in the absence of red cells. However, red cell extracts containing an equivalent concentration of superoxide dismutase caused marked inhibition of cytochrome $c$ reduction. This indicates that intact red cells cannot efficiently scavenge $\mathrm{O}_{2}^{-}$in competition with external ferricytochrome $c$.

Reduction of NBT, which reacts four times more slowly with $\mathrm{O}_{2}^{-}$than does ferricytochrome $c$, was also not affected by adding up to $0.4 \%$ red cells (Table I). However, a red cell extract containing the same concentration of superoxide dismutase as the cell suspension gave detectable inhibition of NBT reduction (at least 20\%) with the equivalent of $0.01 \%$ cells, and complete inhibition with the equivalent of $0.1 \%$ (12.5 $\mu \mathrm{M}$ NBT) or $0.4 \%$ cells ( $50 \mu \mathrm{M}$ NBT). Hence intracellular superoxide dismutase was at least 40 times less efficient than the enzyme in solution.

Hydroxyl radicals. $\mathrm{O}_{2}^{-}$and $\mathrm{H}_{2} \mathrm{O}_{2}$ generated by xanthine oxidase undergo an iron catalyzed reaction, and when the iron is chelated to EDTA, the product is $\mathrm{OH}^{\circ}$, which causes oxidation of deoxyribose (16). Deoxyribose oxidation by this system was progressively inhibited by increasing numbers of red cells (Fig. 4). This was not due to effects of red cells on the xanthine oxidase system. Superoxide production was unaffected by the presence of red cells (see above) as was urate production from hypoxanthine, measured as $\Delta A_{295} / \mathrm{min}$ over a 30 -min period.

Table I. Effect of Red Cells on the Rate of NBT Reduction by Superoxide

\begin{tabular}{llll}
\hline \multirow{2}{*}{$\begin{array}{l}\text { Percent red cell } \\
\text { suspension }\end{array}$} & \multicolumn{3}{l}{ Rate of reduction $\left(\Delta \mathrm{A}_{\mathbf{5 6 0}} / \mathrm{min} \times 10^{3}\right)$} \\
\cline { 2 - 3 } & \multicolumn{2}{l}{ NBT concentration $(\mu \mathrm{M})$} \\
0 & 50 & 25 & 12.5 \\
0.1 & 4.7 & 3.6 & 1.9 \\
0.2 & 6.7 & $\mathrm{ND}$ & 1.7 \\
0.3 & 6.7 & 4.2 & 1.9 \\
0.4 & 5.0 & $\mathrm{ND}$ & $\mathrm{ND}$ \\
& 5.0 & 3.0 & $\mathrm{ND}$ \\
\hline
\end{tabular}

Superoxide was generated from hypoxanthine and xanthine oxidase and was continuously monitored. Variation between duplicates was $\pm 5 \%$ in the absence of red cells, but greater when cells were present due to increased turbidity. NBT reduction could not be assessed by sedimenting the cells and reading the absorbance change after a fixed interval, since some reduced NBT sedimented with the cells. 


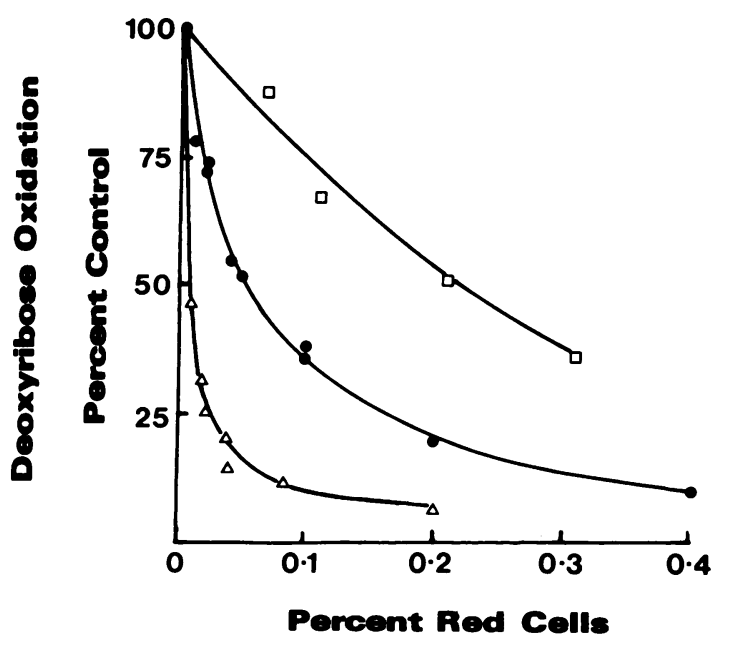

Figure 4. Effects of red cells and catalase on deoxyribose oxidation by a xanthine oxidase-Fe(EDTA) hydroxyl radical generating system. Reaction conditions were as in Methods. In the absence of red cells or catalase, thiobarbituric acid-reaction products gave an $A_{532}$ of 0.50 . ๑, Untreated red cells; $\square$, aminotriazole-treated red cells; $\Delta$, purified catalase at an equivalent concentraion $(\mathrm{U} / \mathrm{ml})$ to the intracellular catalase at each red cell concentration.

Rates of urate production with and without $0.4 \%$ red cells agreed to within $5 \%$. The catalase content of the red cells was measured, and an equivalent concentration of purified catalase was also added to the $\mathrm{OH}^{\circ}$-generating system. As shown in Fig. 4, free catalase inhibited deoxyribose oxidation approximately three times more efficiently than cells containing equivalent activity.

Treatment of the red cells with CO or DDC (which blocked $>90 \%$ of superoxide dismutase activity), had little effect on the extent of inhibition by the cells (Table II). However, aminotriazole pretreatment, which blocked $>98 \%$ of catalase activity, decreased their ability to inhibit deoxyribose oxidation

Table II. Effect of Various Treatments on the Ability of Red Cells to Inhibit $\mathrm{OH}^{\circ}$-mediated Oxidation of Deoxyribose

\begin{tabular}{lcr}
\hline & \multicolumn{2}{c}{$\begin{array}{l}\% \text { Inhibition of } \\
\text { deoxyribose oxidation }\end{array}$} \\
\cline { 2 - 3 } Treatment & $0.1 \%$ red cells & $0.2 \%$ red cells \\
\hline None & $57 \pm 2$ & $74 \pm 2$ \\
CO & $61 \pm 1$ & $74.5 \pm 1$ \\
NEM & ND & $74 \pm 1$ \\
DDC & ND & $76 \pm 1$ \\
Glucose & $65 \pm 2$ & $78 \pm 2$ \\
Aminotriazole & $32 \pm 3$ & $47 \pm 2$ \\
Aminotriazole-CO & ND & $46 \pm 1$ \\
Aminotriazole-NEM & $20 \pm 2$ & $38 \pm 2$ \\
Aminotriazole-glucose & $37 \pm 1$ & $52 \pm 1$ \\
Aminotriazole-ghosts & $1 \pm 1$ & $-1 \pm 3$ \\
None* & $-1 \pm 14$ & $-10 \pm 8$ \\
& &
\end{tabular}

Reactions were carried out under the same conditions as for Fig. 4. Results shown are means \pm deviation of two to four assays.

* $\mathrm{OH}^{*}$ generated by $\gamma$-irradiation. to about a third (Fig. 4 and Table II). NEM (which blocked $>85 \%$ of the GSH) had little effect on its own, but did further decrease inhibition by aminotriazole-treated cells. Inhibition was slightly greater with $0.5 \mathrm{mM}$ glucose present, for both untreated and aminotriazole-treated cells. (Glucose alone did not affect the reaction.)

To determine whether there was any inhibition due to red cells scavenging $\mathrm{OH}^{*}$ or an intermediate in the pathway of deoxyribose oxidation to TBA-reactive products, two systems were examined. $\mathrm{OH}^{\circ}$ should be too short-lived to penetrate the cells, so its reactivity with red cell ghosts and intact cells should be similar. Ghosts equivalent to $0.2 \%$ red cell suspension added to the $\mathrm{OH}^{\circ}$ generating system gave no inhibition of deoxyribose oxidation (Table II). Secondly, the effect of red cells on oxidation of deoxyribose by radiolytic $\mathrm{OH}^{*}$ (which is formed independently of $\mathrm{H}_{2} \mathrm{O}_{2}$ and $\mathrm{O}_{2}^{-}$) was examined. No inhibition by 0.1 or $0.2 \%$ red cells was apparent (Table II). Both these results suggest that the cells inhibited formation of $\mathrm{OH}^{*}$, rather than acting as an $\mathrm{OH}^{*}$ scavenger. One further way red cells could inhibit $\mathrm{OH}^{*}$ production is by binding or taking up the iron catalyst. However, with EDTA present, this would seem unlikely.

Red cells, therefore, can inhibit $\mathrm{OH}^{*}$ production from $\mathrm{O}_{2}^{-}$ and $\mathrm{H}_{2} \mathrm{O}_{2}$. A majority of the effect can be attributed to removal of $\mathrm{H}_{2} \mathrm{O}_{2}$ by intracellular catalase, with a lesser contribution dependent on GSH and glucose metabolism. There was, however, significant inhibition of deoxyribose oxidation that could not be attributed to direct $\mathrm{OH}^{*}$ scavenging or any red cell antioxidant system.

Hypochlorous acid. Stimulated neutrophils, via the myeloperoxidase catalyzed reaction of $\mathrm{H}_{2} \mathrm{O}_{2}$ with chloride, produce $\mathrm{HOCl}(21)$, which can be detected by conversion of methionine to the sulfoxide $(18,22)$. Secondary reactions of $\mathrm{HOCl}$ with primary amines or ammonia can give rise to chloramines, less energetic oxidants, but also able to oxidize methionine (23, 24). As $\mathrm{HOCl}$ reacts $\sim 100$ times faster with methionine than with taurine (19), the excess methionine employed in the experiments described below would be expected to trap almost all the myeloperoxidase-derived $\mathrm{HOCl}$ directly. This supposition is supported by our findings that at no time during the incubation of stimulated neutrophils with methionine did the supernatant cause detectable oxidation of 5-thio-2-nitrobenzoic acid (lower limit of detection $2 \mu \mathrm{M}$ ). This indicates no significant accumulation of long-lived oxidants such as chloramines $(23,24)$ under these conditions. By contrast, in the absence of methionine, 5-thio-2-nitrobenzoic acid oxidation indicated accumulation of $24 \mu \mathrm{M}$ chloramine. We first confirmed that $\mathrm{HOCl}$, in $<1 \mathrm{~min}$, stoichiometrically converted methionine to the sulfoxide. With $1 \mathrm{mM}$ methionine and $12-25 \mu \mathrm{M} \mathrm{HOCl}, 88 \pm 4 \%(n=3)$ of the oxidizing equivalents were recovered as methionine sulfoxide. Amino acid analysis detected no peak in the position of methionine sulfone. The same concentration of $\mathrm{H}_{2} \mathrm{O}_{2}$, over $45 \mathrm{~min}$, gave no reaction. Resting neutrophils did not react, but cells stimulated with phorbol myristate acetate, under the conditions of the assay, gave $\sim 10 \%$ conversion.

As shown in Fig. 5, methionine sulfoxide formation was inhibited by catalase, and was also progressively inhibited by increasing concentrations of suspended red cells. Under similar conditions to Fig. 5, superoxide dismutase $(15 \mu \mathrm{g} / \mathrm{ml})$ did not inhibit methionine oxidation, either by stimulated neutrophils alone (12.3 $\mu \mathrm{M}$ methionine sulfoxide formed compared 


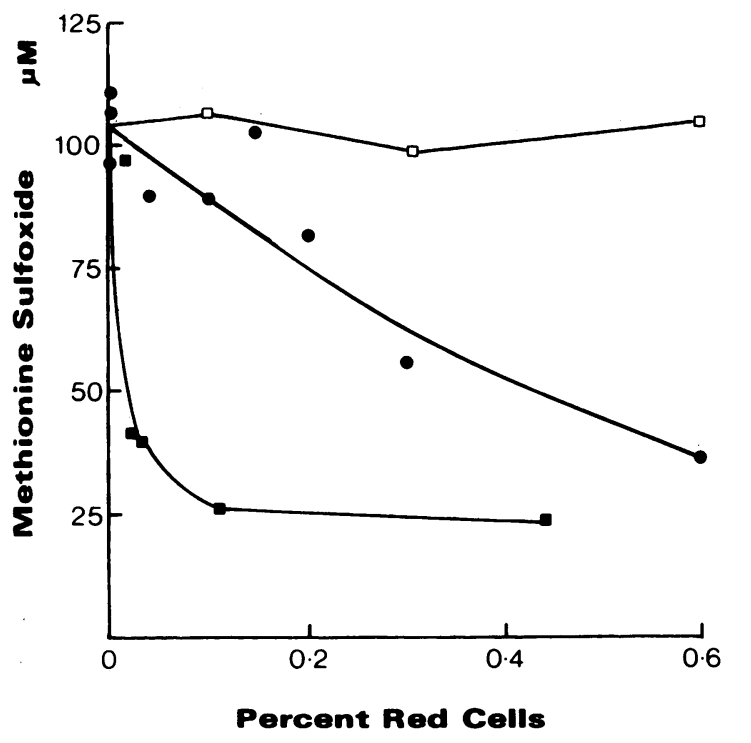

Figure 5. Effects of red cells and catalase on methionine oxidation by stimulated neutrophils. Neutrophils were stimulated with phorbol myristate acetate in the presence of $1 \mathrm{mM}$ methionine, and the concentration of methionine sulfoxide was measured as described in Methods. • Untreated red cells; $\square$ aminotriazole-treated red cells; purified catalase at an equivalent concentration $(\mathrm{U} / \mathrm{ml})$ to the intracellular catalase at each red cell concentration.

with $9.2 \mu \mathrm{M}$ in the control), or in the presence of $0.6 \%$ red cells (4.7 $\mu \mathrm{M}$ compared with $3.5 \mu \mathrm{M}$ in the control). Furthermore, addition of purified myeloperoxidase as (50 nM) slightly enhanced methionine sulfoxide formation by neutrophils alone $(15.0 \mu \mathrm{M})$ and counteracted the effect of $0.6 \%$ red cells $(10.1$ $\mu \mathrm{M}$ sulfoxide formed). Thus a dependence on MPO-derived $\mathrm{HOCl}$ is implied. The cells were not as efficient at inhibiting the reaction as an equivalent concentration of free catalase, but their effect was prevented by inactivating their catalase with aminotriazole. Some methemoglobin formation (but no hemolysis) was apparent by the end of the incubation, both in the presence and absence of aminotriazole.

Red cells $(0.5 \%)$ had no effect on oxidation of methionine by $\mathrm{HOCl}$, indicating that there was sufficient methionine for the cells not to inhibit by direct scavenging. Rather, it appears that they acted by removing $\mathrm{H}_{2} \mathrm{O}_{2}$ and thereby preventing myeloperoxidase-dependent formation of $\mathrm{HOCl}$.

\section{Discussion}

Recent studies have shown that red cells can protect other cells or tissues against injury by extracellularly generated oxidants (7-10). In all these systems, $\mathrm{H}_{2} \mathrm{O}_{2}$ was implicated. Our studies have shown that red cells at low concentrations inhibit reactions involving $\mathrm{H}_{2} \mathrm{O}_{2}, \mathrm{OH}^{\circ}$ and $\mathrm{HOCl}$. We thus provide further evidence for a protective role for red cells, and suggest mechanisms for this antioxidant protection.

With $\mathrm{OH}^{\circ}$ and $\mathrm{HOCl}$, the effects were primarily due to prevention of formation, by removal of $\mathrm{H}_{2} \mathrm{O}_{2}$. High concentrations of very reactive detector compounds were used to minimize a direct scavenging effect. $\mathrm{OH}^{*}$ and $\mathrm{HOCl}$ are so reactive that they will be scavenged by any organic compound, including red cells, at a high enough concentration. In blood they are likely to be scavenged by many constituents, each of which could be susceptible to oxidative damage. Hence it is desirable to prevent formation of these oxidants. We have shown that red cells have this ability.

Thomas et al. (25) have shown that red cells can decrease the accumulation of taurine chloramine formed by stimulated neutrophils in the presence of excess taurine, through direct uptake of the chloramine itself. Our study differs from theirs in that our conditions did not favor chloramine formation, and they did not measure directly the contribution of $\mathrm{H}_{2} \mathrm{O}_{2}$ consumption. However, it does appear that we saw greater peroxide scavenging by red cells than they did. Nevertheless, the two studies demonstrate different mechanisms by which red cells could protect against damage by myeloperoxidase-derived oxidants.

Although our results indicate that red cells without catalase activity have limited ability to inhibit extracellular oxidative reactions, they do not preclude oxidants reacting with other red cell constituents. In fact, hemoglobin oxidation was observed under various conditions. The results do not therefore contradict others showing that $\mathrm{H}_{2} \mathrm{O}_{2}$ or neutrophil-derived chloramines can react with red cell constituents $(25,26)$. Rather they indicate that such reactions consume a minor proportion of each oxidant when extracellular reactants such as ferrocytochrome $c, \mathrm{Fe}(\mathrm{EDTA})$, myeloperoxidase or methionine are present.

In each system we examined, catalase was responsible for the majority of the $\mathrm{H}_{2} \mathrm{O}_{2}$ removal. Aminotriazole treatment abolished the ability of the cells to inhibit ferrocytochrome $c$ oxidation by $\mathrm{H}_{2} \mathrm{O}_{2}$, or methionine oxidation by neutrophils, and had a major effect on $\mathrm{OH}^{\circ}$ production. GSH and glucose metabolism gave some inhibition of $\mathrm{OH}^{*}$ production, and of cytochrome $c$ oxidation at low $\mathrm{H}_{2} \mathrm{O}_{2}$ concentrations, particularly when catalase was inhibited. This probably indicates that the hexose monophosphate shunt can handle lower $\mathrm{H}_{2} \mathrm{O}_{2}$ concentrations over a longer period, but even then, catalase has a much greater effect.

Red cells were at least 40 times less efficient at inhibiting NBT reduction than equivalent extracts of their superoxide dismutase, and we saw no protective effect of red cell superoxide dismutase, either on direct reactions of $\mathrm{O}_{2}^{-}$, or on $\mathrm{OH}^{+}$ production. These results imply that although $\mathrm{O}_{2}^{-}$can pass through the red cell membrane (6), most undergoes extracellular reactions rather than entering the cell and reacting with superoxide dismutase. Red cells would not therefore be expected to provide other cells or tissues much protection from $\mathrm{O}_{2}^{-}$generated in their environment. This may be a more important function for extracellular superoxide dismutase (5), although its concentration in plasma is comparatively low. In contrast, red cells should efficiently remove extracellular $\mathrm{H}_{2} \mathrm{O}_{2}$ and protect surrounding tissue against damage mediated by $\mathrm{H}_{2} \mathrm{O}_{2}$ or its secondary products, $\mathrm{OH}^{*}$ or $\mathrm{HOCl}$. Our results indicate a scavenging ability equivalent to approximately a quarter their catalase content, which means that the potential of red cells to remove $\mathrm{H}_{2} \mathrm{O}_{2}$ from blood is immense.

Considerations that blood plasma is poor in antioxidant enzymes provide a rational basis for intravenous enzyme administration in oxidative stress. Recent evidence suggests that superoxide dismutase in particular can provide remarkable protection against ischemic tissue damage (27). Our results imply that if the enzymes act within the blood stream, superoxide dismutase could modulate reactions of superoxide, but 
administered catalase activity is unlikely to exceed that already present in the red cells.

Our findings that red cells efficiently remove $\mathrm{H}_{2} \mathrm{O}_{2}$ from their environment support the proposal (9) that red cell catalase has an important physiological role in extracellular antioxidant defense. We have shown that through this mechanism, the cells inhibit $\mathrm{OH}^{*}$ production, and also myeloperoxidase-dependent production of $\mathrm{HOCl}$. Since these are the most likely contenders for oxidant-mediated tissue damage by neutrophils and other phagocytes $(4,28)$, our results show how red cells could buffer the environment against harmful effects of these cells.

\section{Acknowledgments}

This work was supported by the Medical Research Council of New Zealand and the National Institutes of Health, ES03425.

\section{References}

1. Stern, A. 1985. Red cell oxidative damage. In Oxidative Stress, H. Sies, editor. Academic Press, Orlando, FL. 331-349.

2. Winterbourn, C. C. 1985. Free-radical production and oxidative reactions of hemoglobin. Envir. Health Persp. 64:321-330.

3. Sutton, H. C., P. C. Roberts, and C. C. Winterbourn. 1976. The rate of reaction of the superoxide radical ion with oxy- and met- haemoglobin. Biochem. J. 155:503-510.

4. Halliwell, B., and J. M. C. Gutteridge. 1986. Oxygen free radicals and iron in relation to biology and medicine. Some problems and concepts. Arch. Biochem. Biophys. 246:501-514.

5. Marklund, S. L., E. Holme, and L. Hellner. 1982. Superoxide dismutase in extracellular fluids. Clin. Chim. Acta. 126:41-51.

6. Lynch, R. E., and I. Fridovich. 1978. Permeation of the erythrocyte stroma by superoxide radical. J. Biol. Chem. 253:4697-4699.

7. Van Asbeck, B., S. Hoidal, G. M. Vercellotti, B. A. Schwartz, C. F. Moldow, and H. S. Jacob. 1985. Protection against lethal hyperoxia by tracheal insufflation of erythrocytes: role of cell glutathione. Science (Wash. DC). 227:756-759.

8. Toth, K. M., D. P. Clifford, E. M. Berger, C. W. White, and J. E. Repine. 1984. Intact human erythrocytes prevent hydrogen peroxidemediated damage to isolated perfused rat lungs and cultured bovine pulmonary artery endothelial cells. J. Clin. Invest. 74:292-295.

9. Agar, N. S., S. M. H. Sadrzadeh, P. E. Hallaway, and J. W. Eaton. 1986. Erythrocyte catalase. A somatic oxidant defense. J. Clin. Invest. 77:319-321.

10. Test, S. T., and S. J. Weiss. 1984. Quantitative and temporal characterization of the extracellular $\mathrm{H}_{2} \mathrm{O}_{2}$ pool generated by human neutrophils. J. Biol. Chem. 259:399-405.

11. Beutler, E. 1984. Red Cell Metabolism. A Manual of Biochemical Methods. 3rd ed. Grune \& Stratton, Orlando, FL.

12. Kelman, S. W., S. G. Sullivan, and A. Stern. 1982. Prima- quine-mediated oxidative metabolism in the human red cell. Lack of dependence on oxyhemoglobin, $\mathrm{H}_{2} \mathrm{O}_{2}$ formation, or glutathione turnover. Biochem. Pharmacol. 31:2409-2414.

13. Winterbourn, C. C. 1985 . Erythrocyte superoxide dismutase levels. In Handbook of Methods in Oxy Radical Research. R. A. Greenwald, editor. CRC Press, Boca Raton, FL. 277-280.

14. Dodge, J. T., C. Mitchell, and D. J. Hanahan. 1963. The preparation and chemical characteristics of hemoglobin-free ghosts of human erythrocytes. Arch. Biochem. Biophys. 100:119-130.

15. Böyum, A. 1968. Isolation of mononuclear cells and granulocytes from human blood. Scand. J. Clin. Lab. Invest. 21(Suppl. 97):77-89.

16. Winterbourn, C. C., and H. C. Sutton. 1986. Iron and xanthine oxidase catalyse formation of an oxidant species distinguishable from $\mathrm{OH}^{*}$ : comparison with the Haber-Weiss reaction. Arch. Biochem. Biophys. 244:27-36.

17. Halliwell, B., and J. M. C. Gutteridge. 1981. Formation of a thiobarbituric acid-reactive substance from deoxyribose in the presence of iron salts-the role of superoxide and hydroxyl radicals. FEBS (Fed. Eur. Biochem. Soc.) Lett. 128:347-351.

18. Tsan, M. F., and J. W. Chen. 1980. Oxidation of methionine by human polymorphonuclear leukocytes. J. Clin. Invest. 65:1041-1045.

19. Winterbourn, C. C. 1985 . Comparative reactivities of various biological compounds with myeloperoxidase-hydrogen peroxide-chloride, and similarity of the oxidant to hypochlorite. Biochim. Biophys. Acta. 840:204-210.

20. Antonini, E., and M. Brunori. 1971. Hemoglobin and Myoglobin in Their Reactions with Ligands. Elsevier/North Holland, Amsterdam. pp. 27, 260.

21. Weiss, S. J., R. Klein, A. Slivka, and M. Webb. 1983. Chlorination of taurine by human neutrophils. Evidence for hypochlorous acid generation. J. Clin. Invest. 70:598-607.

22. Tsan, M., and R. C. Denison. 1981. Oxidation of amino acids by human neutrophils. Inflammation. 5:379-386.

23. Test, S. T., M. B. Lampert, P. J. Ossanna, J. G. Thoene, and S. J. Weiss. 1984. Generation of nitrogen-chlorine oxidants by human phagocytes. J. Clin. Invest. 74:1341-1349.

24. Grisham, M. B., M. M. Jefferson, D. F. Melton, and E. L. Thomas. 1984. Chlorination of endogenous amines by isolated neutrophils. Ammonia-dependent bactericidal, cytotoxic, and cytolytic activities of the chloramines. J. Biol. Chem. 259:10404-10413.

25. Thomas, E. L., M. B. Grisham, D. F. Melton, and M. M. Jefferson. 1985. Evidence for a role of taurine in the in vitro oxidative toxicity of neutrophils toward erythrocytes. J. Biol. Chem. 260:33213329.

26. Grisham, M. B., M. M. Jefferson, and E. L. Thomas. 1984. Role of monochloramine in the oxidation of erythrocyte hemoglobin by stimulated neutrophils. J. Biol. Chem. 259:6757-6765.

27. McCord, J. M. 1985. Oxygen-derived free radicals in postischemic tissue injury. N. Engl. J. Med. 312:159-163.

28. Weiss, S. J., and A. F. LoBuglio. 1982. Biology of disease. Phagocyte-generated oxygen metabolites and cellular injury. Lab. Invest. 47:5-18. 